Kazimierz JAMROZ , Krzysztof WILDE, Marcin BUDZYŃSKI, Łukasz JELIŃSKI, Jacek CHRÓŚCIELEWSKI, Stanisław BURZYŃSKI, Łukasz PACHOCKI

Gdańsk University of Technology (Politechnika Gdańska)

\title{
INNOVATIVE RESEARCH INTO ROAD RESTRAINT SYSTEMS
}

\section{Innowacyjne badania systemów powstrzymujących pojazd przed wypadnięciem $\mathrm{z}$ drogi}

\begin{abstract}
Key to understanding the needs and building road infrastructure management tools to prevent and mitigate run-off-road accidents is to identify hazards and their sources which are a result of wrong design, construction, installation and maintenance of road restraint systems [1]. Building such tools requires advanced studies with field tests, simulations and models [30]. Delivered under the Road Innovation programme, two research projects (ROSE and LifeROSE) are designed to help with that. The main aim of the projects is to develop a method to help with an optimal choice of road restraint systems.
\end{abstract} Keywords: road safety, safety barriers, crash tests

Streszczenie: Kluczem do zrozumienia potrzeb i budowania narzędzi do zarzadzania infrastruktura drogowa, $w$ celu zapobiegania wypadkom drogowym $i$ tagodzenia ich skutków, jest identyfikacja zagrożen i ich źródet, które sa wynikiem niewtaściwego projektowania, budowy, instalacji i utrzymania systemów powstrzymujacych pojazd przed wypadnięciem z drogi [1]. Budowanie takich narzędzi wymaga zaawansowanych badań $z$ wykorzystaniem testów zderzeniowych, symulacji $i$ modeli [30]. Badania takie prowadzone sa $w$ dwóch projektach badawczych (ROSE i LifeROSE) realizowanych $w$ ramach programu badawczego Rozwój Innowacji Drogowych. Głównym celem tych projektów jest opracowanie metod wyboru optymalnych systemów zabezpieczajacych pojazdy przed wypadnięciem z drogi. w zależności od: rodzaju i wielkości zagrożenia.

Słowa kluczowe: bezpieczeństwo ruchu drogowego, bariery drogowe, badania poligonowe 


\section{Description of the problem}

Roadside (hard shoulder, ditch, an area directly adjacent to the road) accidents occur when vehicles run off the road. Because these accidents usually involve hitting a fixed roadside obstacle (tree, utility pole, structure support, culvert front wall, barrier), the majority are quite severe. Approximately $19 \%$ [7] of all people killed in road accidents in Poland died in roadside-related accidents. These include: hitting a tree (a main hazard), hitting a barrier, a utility pole or road sign and vehicle roll-over on an embankment or ditch.

A safety barrier is designed to protect people and roadside objects from being hit by an errant vehicle. Barriers help to reduce the severity and consequences of run-off-road accidents for the road users involved (drivers and car occupants) and thus help to mitigate the consequences of running off the road. Unfortunately safety barriers are not neutral because they contribute to barrier and vehicle damage. One of the objectives of ROSE and LifeROSE was to identify and analyse factors that affect barrier design parameters and change barrier functionality when hit by a vehicle. Because identifying the effects of all factors on barriers is very difficult, two research methods are used in practice: statistical and mechanistic methods [9].

Statistical methods use available detailed data about dangerous road incidents to extract real cases of vehicles hitting safety barriers. Data are collected about the location of the incident, barrier design conditions, road traffic and other circumstances of the incidents. Next, using the data mathematical models are built which define the relation between barrier functional parameters and the frequency and scale of vehicle crashes into barriers and of other significant factors. A review of the available research on the effects of roadside on road safety shows that research is largely focused on how selected road parameters (road width, type and width of hard shoulder, roadside trees and road signs), road structures (bridges, culverts road signs), roadside obstacles (trees, poles) and road equipment (road barriers and fencing) influence run-off-road accident risks $[2,17,18]$. The study results were used to model and simulate the effects of different combinations of road geometric parameters and traffic parameters on accident frequency and consequences $[1,12]$. The focus of other research has been on "forgiving" roads which found the clear zone to be very important $[20,25]$. The results of research were used to inform new guidelines and examples of good practice $[23,27]$. The RISER project was a key contributor of this [10]. It was designed to determine the behaviour of drivers (in adjusting speed) in relation to the conditions encountered. Another project, SAVER, looked at how road safety devices (including safety barriers) are applied across Europe [13]. Despite the different conditions and hazards, the roadside presents a major problem in all of them. This calls for 
effective and efficient solutions to take account of, among other things, object lifecycle $[15,21]$. In Poland research results on the roadside and safety barriers can be found in publications by the authors $[5,6,7,8]$.

Mechanistic methods use physical relations to calculate barrier functional parameters following a vehicle impact; they help to understand the physical relations (interactions) between vehicles and a safety barrier. The most frequently used relations are those between the force with which a vehicle impacts a barrier and vehicle mass, impact speed and impact angle [29, 31]. The resulting models are applied to single crashes, i.e. a vehicle hitting a specific barrier, and are not usually used to describe the effects of a group of incidents on road sections (in which case the frequency of specific types of incidents is summed up). This approach is used when historical barrier accident data are not available. Mechanistic methods include those that are based on field crash tests and numerical crash tests. It is generally considered that results from real crash tests are not questioned [28] and are used to validate numerical models. It is important to note, however, that while crash test standards are rigorously observed, [14], not all mistakes can be eliminated [11]. Field tests are complemented and extended with numerical tests [16, 32]. In

the first stage, the numerical model is checked for correctness $[3,14]$. In Poland crash test numerical modelling is studied extensively by a few centres $[4,22,24$, 26], and by the authors [19].

\section{Study method}

\subsection{Objective and scope of the study}

Mechanistic tests were conducted on crash test datasets (own tests and barrier manufacturers' tests) and on numerical tests. This article presents the methodology and selected results of crash tests conducted at a test site. The objective of the analyses was to understand how the field crash tests can be used to define the effect of the impact energy on the barrier's functional parameters and its design features which determine its resistance to deformation.

\subsection{Characteristics of the crash tests}

Set of field crash tests. A set of 25 tests was analysed combining LifeROSE (3 tests), ROSE (9 tests) and barrier manufacturers' tests (13 tests). Reports were produced for 3 concrete barrier crash tests, 4 wire rope barrier crash tests and 18 steel barrier crash tests. 
Scope of available data. A report was written for each crash test providing the following data:

- test data: test number, type of test (in the field, simulation), type of examination, detailed characteristics of the test,

- barrier data: type, barrier manufacturer's type and number, barrier width, post spacing,

- vehicle data; type of vehicle, mass of vehicle, impact speed and impact angle,

- barrier parameters after impact: normalised working width, dynamic deflection, maximal sustained deformation, length of contact between vehicle and barrier, length of barrier damage, number of barrier segments that need replacing, number of damaged posts,

- incident severity indices: ASI, THIV,

- comments and remarks: such as location of the vehicle after the impact (went through the barrier, stopped before the barrier, etc.),

- video and photographic incident documentation.

Under ROSE and LifeROSE 12 field crash tests were conducted in accordance with the standard PN EN-1317:2010 (fig. 1):

- TB32 (vehicle with a mass of $1500 \mathrm{~kg}$, impact speed $110 \mathrm{~km} / \mathrm{h}$, impact angle $20^{\circ}$ ) for a road wire rope barrier for a section of a barrier installed on a curve with a radius of 400 metres (two impacts),

- TB32 for a road steel barrier for a section of a barrier installed on a horizontal curve with a radius of 400 metres (two impacts),

- TB11 (vehicle with a mass of $900 \mathrm{~kg}$, impact speed $100 \mathrm{~km} / \mathrm{h}$, impact angle $20^{\circ}$ ) for a bridge barrier with a kerb $14 \mathrm{~cm}$ high (two impacts),

- TB51 (vehicle with a mass of $13000 \mathrm{~kg}$, impact speed $70 \mathrm{~km} / \mathrm{h}$, impact angle $20^{\circ}$ ) for a bridge barrier with a kerb $14 \mathrm{~cm}$ high,

- TB32 for the connection between a road wire rope barrier with a steel barrier,

- TB51 for a road steel barrier and a lighting pole placed within the barrier's working width,

- TB41 (vehicle with a mass of $10000 \mathrm{~kg}$, impact speed $70 \mathrm{~km} / \mathrm{h}$, impact angle $8^{\circ}$ ) for a concrete barrier,

- TB32 for a road wire rope barrier (impact angle $7^{\circ}$ ),

- TB32 for a road steel barrier (impact angle $7^{\circ}$ ). 

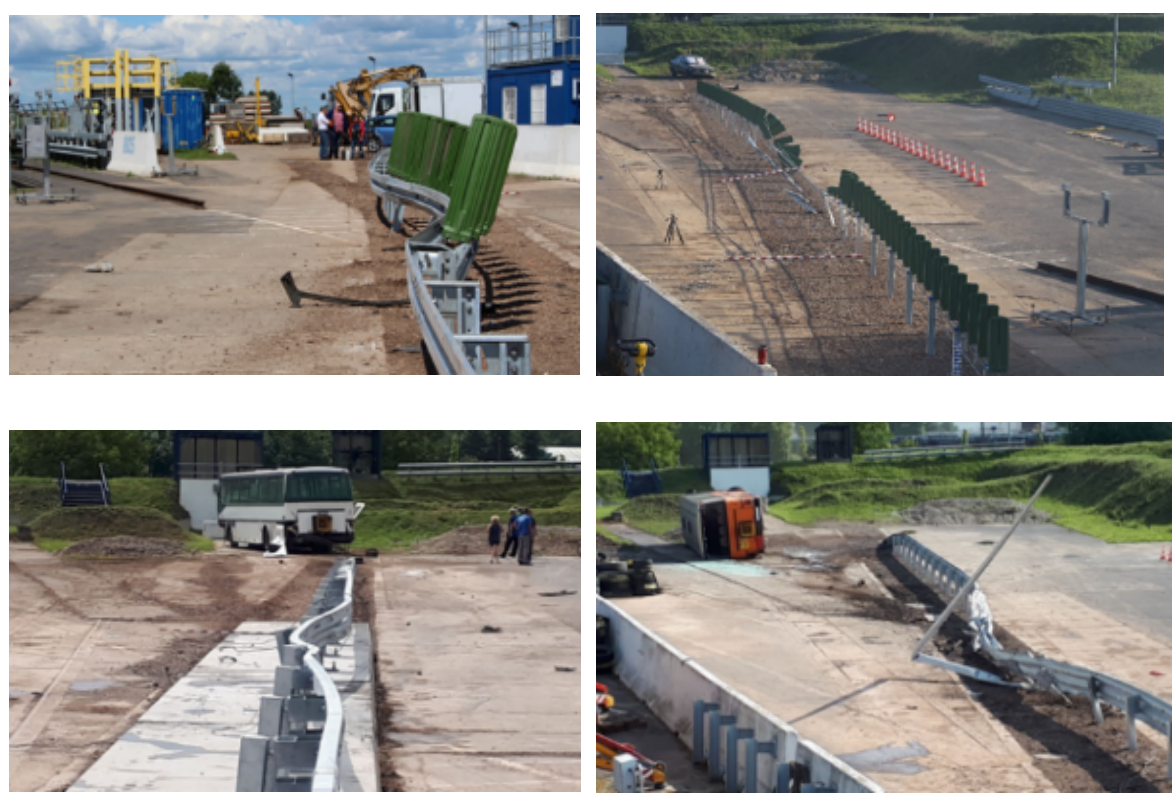

Fig. 1. Photographic documentation of the crash tests conducted for the ROSE project

\subsection{Analysis of test results}

Collected during the crash tests, the data helped to analyse the effects of vehicle-barrier impact energy on the barrier's functional parameters. When a vehicle hits a barrier, the barrier deflects or sustains damage. Barrier deflection following a vehicle impact depends on the energy with which the vehicle hits the barrier and on its designed flexibility. The lateral kinetic energy of a vehicle hitting a barrier EKL depends on vehicle mass MP, impact speed VP and impact angle of the vehicle hitting the barrier KU. Lateral kinetic energy EKL of the vehicle hitting a safety barrier is defined using this formula (1):

$$
E K L=\frac{M P \cdot(V P \cdot \sin (K U))^{2}}{2}
$$

Barrier deflection upon impact of a normative vehicle is defined using normalised values of: dynamic deflection DM and working width WM. Deflection performance_of barriers upon vehicle impact may be measured with stiffness $\mathrm{K}$ and working width WM.

Barrier design stiffness $\mathrm{K}$ is the barrier's ability to resist vehicle impact and may be measured as the quotient of the force of an impacting vehicle and barrier 
displacement as a result of the impact. Safety barrier stiffness K may be defined using the formula (2):

$$
K=\frac{M P \cdot(V P \cdot \sin (K U))^{2}}{D M^{2}}
$$

The severity level (intensity) of a vehicle impacting a barrier defines the level of injury which may be sustained by vehicle occupants as the vehicle hits a barrier of a specific containment level. The impact intensity level is measured using ASI, defined with formula (3) whose parameters are defined during the crash test.

$$
A S I=\max \left[\left(\frac{a_{x}}{12 g}\right)^{2}+\left(\frac{a_{y}}{9 g}\right)^{2}+\left(\frac{a_{z}}{10 g}\right)^{2}\right]^{\frac{1}{2}}
$$

Symbols:

EKL - lateral (side) kinetic energy of vehicle $(\mathrm{kJ})$,

MP - vehicle mass $(\mathrm{kg})$,

VP - speed of vehicle impact on barrier $(\mathrm{m} / \mathrm{s})$,

KU - angle of vehicle impact on barrier (degrees),

DM - dynamic deflection of barrier after vehicle impact $(\mathrm{m})$,

$\mathrm{K}$ - safety barrier stiffness $\left(\mathrm{kN} / \mathrm{m}, \mathrm{kJ} / \mathrm{m}^{2}\right)$,

$a_{x, y, z}$ - average vehicle acceleration measured during crash test, longitudinal, lateral and vertical respectively measured over a specific time interval (50 milliseconds).

\section{Results}

Based on the crash tests, a study was carried out into the effects of the energy of vehicle impact into a barrier EKL on the barrier's functional parameters. This involved a set of analyses to help define the effects of vehicle barrier impacts on those barrier parameters which are important for modelling barrier estimated dynamic deflection DM, working width WM and severity indices ASI. Barrier dynamic deflection DM represents the dynamic work of a barrier on impact. Based on the crash test data, models were developed of the relation between barrier dynamic deflection DM and barrier stiffness K, lateral kinetic energy of a vehicle hitting the barrier EKL and vehicle mass MP (4).

$$
D M=4,7 \cdot K^{-0,5} \cdot \exp \left(1,1 \cdot \frac{E K L}{100}-0,14 \cdot \frac{M P}{1000}\right)
$$


Fig. 2 shows the relation between normalised barrier dynamic deflection DM and barrier stiffness $\mathrm{K}$, lateral kinetic energy of a vehicle hitting the barrier EKL and vehicle mass MP. Barrier dynamic deflection DM increases as the vehicle's lateral kinetic energy grows EKL. It decreases as barrier stiffness $\mathrm{K}$ and vehicle mass MP hitting the barrier grow. Barrier working width WM is a technical parameter which characterises barrier stiffness or its flexibility to vehicle impacts and is used for designing barriers in road cross-section. Using the crash test data, models were developed to represent the relation between barrier working width WM and barrier dynamic deflection DM and barrier width WB (5).

$$
W M=0,87 \cdot D M^{1,28}+1,005 \cdot W B
$$

Figure 3 shows a chart of the relation between normalised working width WM and dynamic deflection DM and barrier width WB. The data shows that barrier working width WM increases as dynamic deflection DM and barrier width WB increase. The severity (intensity) of vehicle crash against the barrier measured with ASII defines the level of injury severity sustained by vehicle occupants upon impact for a specific barrier stiffness.

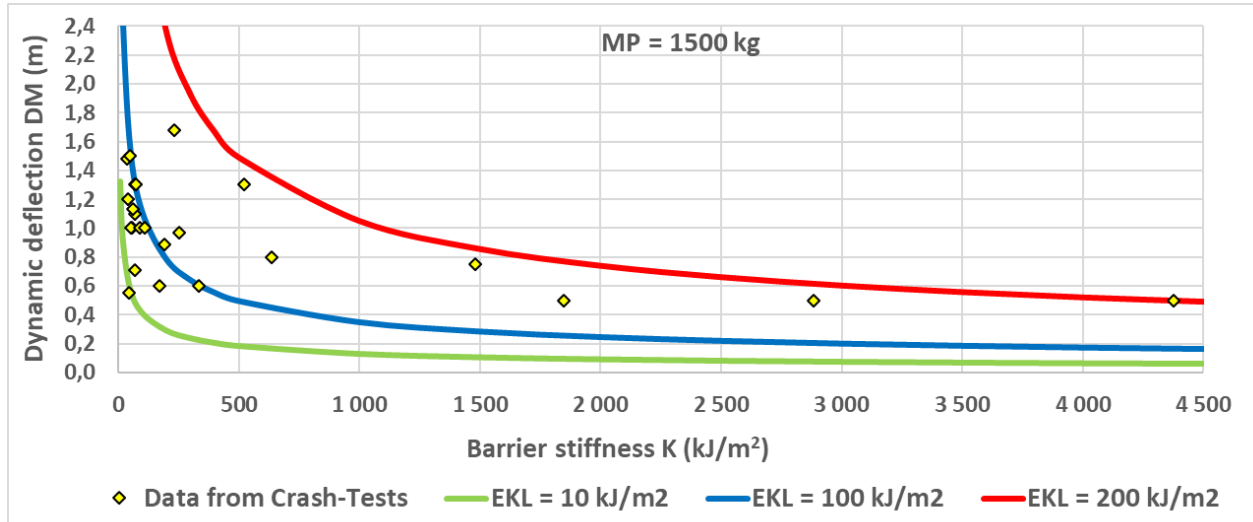

Fig. 2. Relation between normalised dynamic deflection DM and barrier stiffness K, lateral kinetic energy EKL of the vehicle impacting the barrier and vehicle mass MP

The crash test data were also used to model the relation between the crash intensity index ASI and barrier dynamic deflection DM, lateral kinetic energy EKL and longitudinal kinetic energy EKP (6).

$$
A S I=1,64 \cdot \exp \left(7,72 \cdot \frac{E K L}{1000}+1,24 \cdot \frac{E K P}{1000}-0,68 \cdot D M\right)
$$




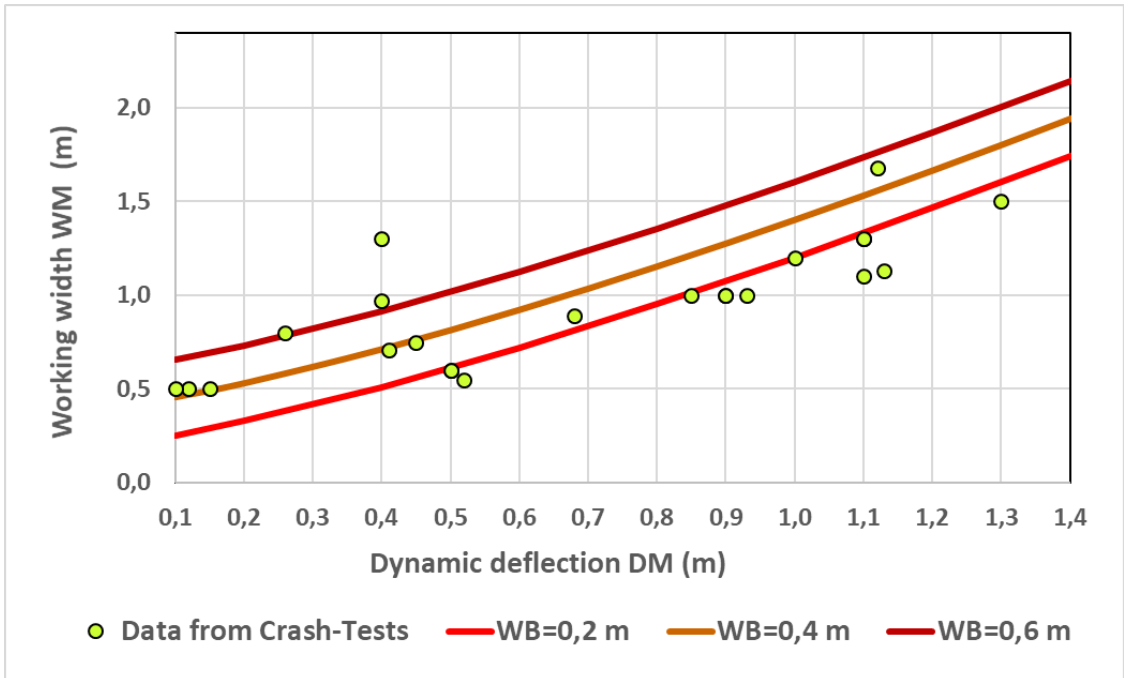

Fig. 3. Relation between barrier dynamic deflection DM and barrier working width WM

Figure 4 shows the relation between ASI and barrier dynamic deflection DM and lateral kinetic energy of the vehicle EKL. The ASI index increases as barrier stiffness grows (dynamic deflection DM decreases) and lateral kinetic energy EKL of the vehicle hitting a safety barrier increases.

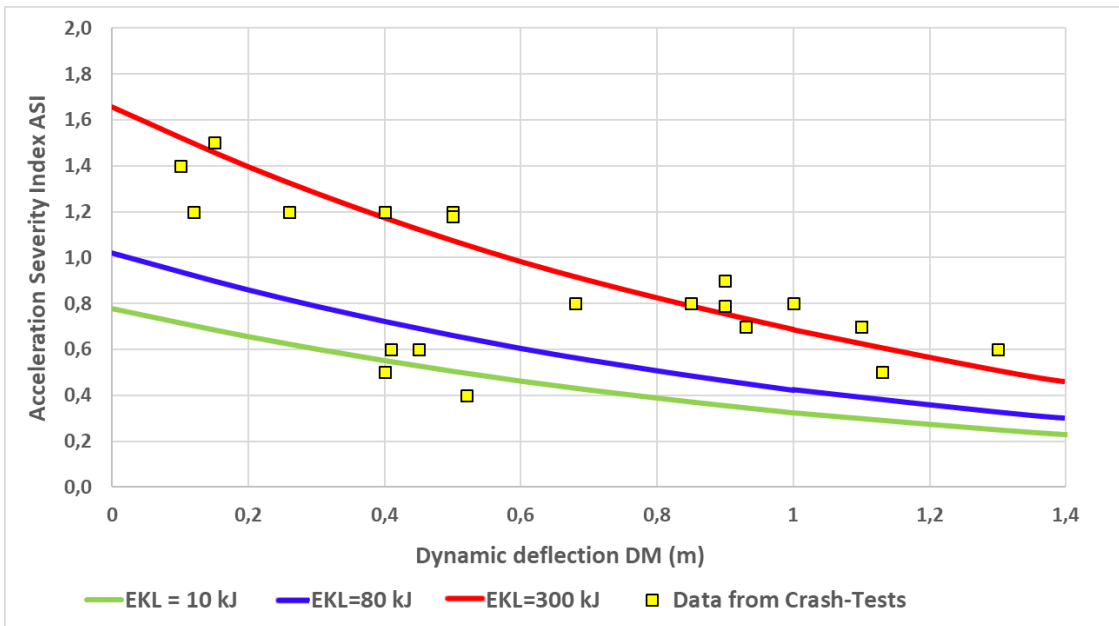

Fig. 4. Model relations between barrier dynamic deflection DM and ASI index 


\section{Summary}

It is critical that modern methods for the design, construction and operation of road infrastructure are based on research into how specific types of road safety devices and their application under different road and traffic conditions affect the functionality and safety of road infrastructure devices which are key to ensuring safe road infrastructures. The results of the research will be used to develop a set of recommendations to inform guidelines for designers, manufacturers and contractors and maintenance instructions. If applied, the guidelines will help to shape a safe road infrastructure and eliminate the most common mistakes. Thanks to the field tests, it was possible to provide a preliminary description of the factors which determine the level of damage sustained by barriers hit by vehicles and the hazards to car occupants. The results were analysed and it can be concluded that:

- basic design parameters of barrier, i.e. working width WM and dynamic deflection DM, depend on barrier stiffness (measured with $\mathrm{K}$ parameter) and lateral kinetic energy EKL of the vehicle impacting a barrier,

- incident severity ASI increase as barrier stiffness (measured with dynamic deflection DM) and lateral kinetic energy EKL of a vehicle impacting a barrier grow.

The standard field crash tests of vehicles impacting with safety barriers were analysed to study the effect on safety barrier functional and structural parameters. Only selected factors of the vehicle impact with barriers could be identified for their effect. Yet the crash test results can be used to calibrate numerical models of safety barriers for simulation test purposes. As a result, the scope of testing can be extended. The results of simulation tests will be presented in new publications.

\section{References}

1. AASHTO. Roadside Design Guide, 2011.

2. Ambros J., Havránek P., Valentová V., Křivánková Z., Striegler R.: Identification of Hazardous Locations in Regional Road Network - Comparison of Reactive and Proactive Approaches. Transp. Res. Procedia, vol. 14, 2016.

3. Barnat W., Bogusz P. Dziewulski P., Gieleta R., Kiczko A., Klasztorny M., Niezgoda T., Ochelski S.: Experimental validation of the numerical model of a car impact on a road barrier, Journal of KONES Powertrain and Transport, Vol. 17, No. 1, 2010.

4. Borkowski W., Hryciów Z., Rybak P., Wysocki J., Wiśniewski A.: Studies on the effectiveness of the innovative road safety system, Journal of KONES Powertrain and Transport, Vol. 21, No. 2, 2014. 
5. Budzyński M., Gobis A., Jamróz K., Jeliński L., Ostrowski K.: Road Restraint Systems as a Basis for Roadside Safety Improvement. WMCAUS 2018, IOP Conference Series: Materials Science and Engineering, 2019.

6. Budzyński M., Jamróz K., Jeliński Ł.: Assessment of Road Restraint Systems in Polish Conditions. Journal of KONBiN, vol. 45, iss. 1, 2018, doi.org/10.2478/jok-2018-0017.

7. Budzyński M., Jamróz K., Marcin A.: Effect of the Road Environment on Road Safety in Poland. WMCAUS 2017: IOP Conference Series: Materials Science and Engineering, vol. 245, 2017.

8. Budzyński M., Jamróz K., Jeliński L., Antoniuk M.: Why are Trees Still Such a Major Hazard to Drivers in Poland?. Transport Research Arena 2016. Transportation Research Procedia, 2016.

9. Burbridge A., Troutbeck R.: Decompartmentalising road safety barrier stiffness in the context of vehicle occupant risk. Proceedings of the 2016 Australasian Road Safety Conference, Australia 2017.

10. De Ridder S., Van der Horst R., Naing C., Thomson R.: Identify envelope of vehicle and driver response prior to collisions. RISER, 2006.

11. EN 1317-2:2010. Road restraint systems - Part 2: Performance classes, impact tests acceptance criteria and test methods for safety barriers including vehicle parapets.

12. Fitzpatrick C. D.: The Effect of Roadside Elements on Driver Behavior and Run-Offthe-Road Crash Severity, 2014.

13. Francesca P., Torre L.: SAVeRS Selection of Appropriate Vehicle Restraint Systems. 2014.

14. Goubel C., Di Pasquale E., Massenzio M., Ronel S.: Comparison of crash tests and simulations for various vehicle restraint systems. 7th European LS-DYNA Conference, Salzburg, Austria 2009.

15. Grzyl B., Kristowski A., Jamróz K., Gobis A.: Methods of estimating the cost of traffic safety equipment's life cycle. MATEC Web Conf., 2017.

16. Hallquist J. O.: LS-DYNA theory manual. Livermore Software Technology Corporation, 2006.

17. Holdridge J. M., Shankar V. N., Ulfarsson G. F.: The crash severity impacts of fixed roadside objects. J. Safety Res., vol. 36, no. 2, 2005.

18. Jamieson N., Waibl G., Davies R.: Use of roadside barriers versus clear zones, 2013.

19. Jamróz K., Burzyński S., Witkowski W., Wilde K.: Numerical methods for the assessment of bridge safety barriers. In M. Kleiber et al., eds. Advances in Mechanics: Theoretical, Computational and Interdisciplinary Issues, Gdańsk 2015.

20. Jurewicz C., Troutbeck R. J., Jurewicz C., Troutbeck R.: A Safe System-based approach to selection of clear zones, safety barriers and other roadside treatments. Australas. Road Saf. Res. Polic. Educ. Conf., 2012.

21. Karim H., Magnusson R., Natanaelsson K.: Life-Cycle Cost Analyses for Road Barriers. J. Transp. Eng., vol. 138, no. 7, 2012.

22. Klasztorny M., Zielonka K., Nycz D. B., Posuniak P., Romanowski R. K.: Experimental validation of simulated TB32 crash tests for SP-05/2 barrier on 
horizontal concave arc without and with composite overlay. Arch. Civ. Mech. Eng, vol. 18, 2018, doi:10.1016/j.acme.2017.07.007.

23. La Torre F.: Forgiving Roadsides Design Guide. CEDR, 2012.

24. Niezgoda T., Barnat W., Dziewulski P., Kiczko A.: Numerical modelling and simulation of road crash tests with the use of advanced CAD/CAE systems. Journal of KONBiN, 3 (23), 2012, DOI 10.2478/jok-2013-0041.

25. Norwegian Public Roads Administration, Vehicle Restraint Systems and Roadside Areas. NPRA Directorate of Public Roads, 2014.

26. Nycz D. B.: Comparison of functionality of type a and $b$ guide rails of steel road safety barriers. The Baltic Journal of Road and Bridge Engineering, vol. 13(3), 2018.

27. Ogden K. W.: Safer roads: a guide to road safety engineering. Avebury Technical, 1996.

28. PD CEN/TR 16303:2012 Road restraint systems - Guidelines for computational mechanics of crash testing against vehicle restraint system, 2012.

29. Ray M. H., Asce M., Silvestri C., Conron C. E. Mongiardini M.: Experience with Cable Median Barriers in the United States: Design Standards, Policies, and Performance. Journal of Transportation Engineering, 2009.

30. Ren Z., Vesenjak M.: Computational and experimental crash analysis of the road safety barrier. Engineering Failure Analysis, vol. 12, iss. 6, 2005.

31. Sicking D. L., Ross Jr. H. E.: Benefit-Cost Analysis of Roadside Safety Alternatives. Transportation Research Record, 1986.

32. Vasenjak M., Borovinšek M., Ren Z.: Computational simulations of road safety barriers using LS-DYNA, 6. LS-DYNA Anwenderforum, Frankenthal, DYNAmore GmbH, 2007. 


\section{INNOWACYJNE BADANIA SYSTEMÓW POWSTRZYMUJĄCYCH POJAZD PRZED WYPADNIECCIEM Z DROGI}

\section{Opis zagadnienia}

Wypadki drogowe, które mają miejsce w otoczeniu dróg (na poboczu, w rowie, terenie przyległym bezpośrednio do drogi) są konsekwencją wypadnięcia pojazdu z jezdni. W większości są to wypadki o bardzo dużej ciężkości, gdyż efektem wypadnięcia $\mathrm{z}$ drogi jest bardzo często uderzenie pojazdu w przeszkodę trwałą (drzewo, słup, podporę obiektu, ściankę czołową przepustu, barierę) znajdującą się w tym obszarze. Około 19\% [7] wszystkich ofiar śmiertelnych wypadków drogowych w Polsce, to ofiary wypadków związanych z otoczeniem drogi, do których zaliczamy: najechanie na drzewo (co jest głównym zagrożeniem), najechanie na barierę, najechanie na słup lub znak drogowy, wywrócenie pojazdu na poboczu, na skarpie lub w rowie.

Bariera drogowa zapewnia ochronę osób i obiektów znajdujących się poza drogą przed uderzeniem w nie, wypadającego $z$ drogi pojazdu oraz przyczynia się do zmniejszenia ciężkości, a także skutków wypadnięcia pojazdu z drogi dla uczestników ruchu uczestniczących w takim zdarzeniu (kierowców i pasażerów pojazdów), czyli przyczynia się do zmniejszenie skutków wypadnięcia pojazdu $z$ drogi. Bariera drogowa niestety nie jest obojętna na drodze, ponieważ przyczynia się do powstawania uszkodzeń pojazdu i występowania ofiar. Jednym z celów projektów badawczych ROSE i LifeROSE była identyfikacja i analiza czynników wpływających na parametry konstrukcyjne barier drogowych oraz zmianę ich funkcjonalności w wyniku uderzeń pojazdów. Określenie wpływu wszystkich czynników na funkcjonowanie barier drogowych jest bardzo trudne, dlatego w praktyce stosowane są dwie metody badawcze służące do ich określania: metody statystyczne i metody mechanistyczne [9].

Metody statystyczne polegają na tym, że na podstawie dostępnych, szczegółowych danych o zdarzeniach niebezpiecznych na drogach identyfikuje się rzeczywiste przypadki uderzenia pojazdu w barierę drogową, zbiera dane: o miejscu zdarzenia, warunkach konstrukcyjnych barier, o ruchu drogowym i innych okolicznościach tych zdarzeń. Korzystając $\mathrm{z}$ danych zebranych w bazach buduje się modele matematyczne, 
określające zależność parametrów funkcjonalnych barier oraz częstości i wielkości uderzeń pojazdu w barierę drogową oraz innych najbardziej istotnych czynników. Przegląd dotychczas wykonanych badań wskazuje, że w zakresie oceny wpływu otoczenia na brd, dominującym nurtem badań jest poszukiwanie wpływu wybranych parametrów drogi (szerokość jezdni, rodzaj i szerokość pobocza, drzewa i znaki drogowe przy drodze), wpływu obiektów drogowych (mosty, przepusty, znaki drogowe), przeszkód przy drodze (drzewa, słupy) oraz urządzeń drogowych (bariery drogowe i wygrodzenia) na zagrożenie wypadkami związanymi z wypadnięciem pojazdu z drogi $[2,17,18]$. Wyniki tych badań wykorzystano do modelowania, a także symulowania wpływu różnych kombinacji parametrów geometrycznych drogi oraz parametrów ruchu, na częstość i skutki wypadków $[1,12]$. W innych badaniach skupiono się na drogach „wybaczających błędy kierowców”, dla których istotne okazały się strefy przy jezdni wolne od przeszkód [20, 25]. Wyniki prowadzonych badań wykorzystywane były do opracowania wytycznych i przykładów dobrej praktyki [23, 27]. Jedną z ważniejszych prac w tym zakresie był projekt RISER [10]. Miał on za zadanie określić zachowania kierowców (w dostosowywaniu prędkości) w stosunku do napotkanych warunków otoczenia. Inny projekt, SAVER dotyczył uwarunkowań stosowania urządzeń bezpieczeństwa ruchu drogowego (w tym barier drogowych) w Europie [13]. Dla różnych uwarunkowań i zagrożeń, wspólne jest jednak to, że wszędzie otoczenie dróg jest poważnym problemem bezpieczeństwa oraz konieczne jest szukanie skutecznych i efektywnych rozwiązań, uwzględniających również cykl życia obiektu $[15,21]$. W Polsce, wyniki badań dotyczących wpływu otoczenia dróg, a także barier drogowych można znaleźć w publikacjach autorów $[5,6,7,8]$.

Metody mechanistyczne polegają na tym, że do obliczenia wielkości parametrów funkcjonalnych drogowych barier ochronnych w wyniku uderzenia pojazdu w barierę wykorzystuje się zależności fizyczne, które pozwalają na zrozumienie fizycznej zależności (interakcji) między pojazdami i barierą drogową. Najczęściej wykorzystuje się zależności między siłą uderzenia pojazdu w barierę drogowa w zależności od masy pojazdu, prędkości i kąta uderzenia pojazdu w barierę [29, 31]. Opracowane w ten sposób modele dotyczą pojedynczych uderzeń pojazdu w określoną barierę, rzadziej wykorzystuje się je do opisu efektu występowania grupy zdarzeń na odcinkach dróg (wówczas stosuje się sumowanie występowania częstości występowania różnych rodzajów zdarzeń). To podejście wykorzystywane jest, gdy nie mamy dostępu do historycznych danych o wypadkach z barierami drogowymi. Wśród metod mechanistycznych można wyróżnić te oparte na zderzeniowych testach poligonowych oraz na zderzeniowych testach numerycznych. Ogólnie przyjęło się, że wyniki uzyskane z rzeczywistych testów zderzeniowych nie są podważane [28] i na ich podstawie przeprowadza się walidacji modelów numerycznych. Należy pamiętać, że pomimo przestrzegania norm 
opisujących sposób przeprowadzania testów zderzeniowych [14], nie da się wyeliminować wszystkich błędów podczas ich wykonywania [11]. Uzupełnieniem i rozszerzeniem badań poligonowych są testy numeryczne $[16,32]$. Pierwszym ich etapem jest ocena poprawności modelu numerycznego $[3,14]$. W Polsce w kilku ośrodkach prowadzone są liczne badania z zakresu modelowania numerycznego testów zderzeniowych [4, 22, 24, 26], w tym również przez zespół autorów [19].

\section{Metoda badań}

\subsection{Cel i zakres badań}

Badania mechanistyczne przeprowadzono na zbiorach danych uzyskanych z testów zderzeniowych (własnych i użyczonych przez producentów barier) oraz badań numerycznych. W niniejszym artykule przedstawiono metodykę i wybrane wyniki przeprowadzonych testów zderzeniowych na poligonie badawczym. Celem prowadzonych analiz było określenie możliwości wykorzystania przeprowadzonych testów zderzeniowych na poligonach badawczych do określenia wpływu energii uderzenia pojazdu w barierę na zmianę parametrów funkcjonalnych drogowej bariery ochronnej oraz jej cech konstrukcyjnych wpływających na odporność na odkształcenia.

\subsection{Charakterystyka testów zderzeniowych}

Zbiór poligonowych testów zderzeniowych. Do analiz wykorzystano zbiór 25 badań testowych przeprowadzonych w ramach projektów LifeROSE (3 testy) i ROSE (9 testów), a także udostępnionych przez producentów barier (13 testów). $\mathrm{W}$ rezultacie uzyskano raporty z 3 testów zderzeniowych dla barier betonowych, 4 testy dla barier linowych oraz 18 testów dla barier stalowych.

Zakres dostepnych danych. $\mathrm{Z}$ każdego testu zderzeniowego sporządzane były raporty, z których wybierano następujące dane:

- dane o badaniu: numer badania (testu), rodzaj testu (poligonowy, symulacyjny), rodzaj badania, charakterystyka szczegółowa badania,

- dane o barierze: typ, rodzaj i numer producenta bariery, szerokość bariery, rozstaw słupków,

- dane o pojeździe; rodzaj pojazdu, masa pojazdu, prędkość uderzenia i kąt uderzenia pojazdu w barierę,

- dane o parametrach bariery po uderzeniu pojazdu: znormalizowana szerokość pracująca, ugięcie dynamiczne, maksymalna trwała deformacja, długość styku pojazdu z barierą, długość uszkodzeń bariery, liczba segmentów bariery do wymiany, liczba uszkodzonych słupków, 
- wskaźniki ciężkości zderzenia: ASI, THIV,

- uwagi i komentarze: np. informacja o lokalizacji pojazdu po uderzeniu (przebił barierę, zatrzymał się pod barierą itp.),

- dokumentacja filmowa i fotograficzna z przebiegu zdarzenia.

W ramach projektów ROSE i LifeROSE wykonano 12 testów poligonowych, zgodnie z normą PN EN-1317:2010 (rys. 1):

- TB32 (pojazd o masie $1500 \mathrm{~kg}$, prędkość uderzenia $110 \mathrm{~km} / \mathrm{h}$, kąt uderzenia $20^{\circ}$ ) dla drogowej bariery linowej dla odcinka bariery zainstalowanej na łuku o promieniu 400 metrów (dwa uderzenia),

- TB32 dla drogowej bariery stalowej dla odcinka bariery zainstalowanego na łuku poziomym o promieniu 400 metrów (2 uderzenia),

- TB11 (pojazd o masie $900 \mathrm{~kg}$, prędkość uderzenia $100 \mathrm{~km} / \mathrm{h}$, kąt uderzenia $20^{\circ}$ ) dla bariery mostowej z krawężnikiem o wysokości $14 \mathrm{~cm}$ ( 2 uderzenia),

- TB51 (pojazd o masie $13000 \mathrm{~kg}$, prędkość uderzenia $70 \mathrm{~km} / \mathrm{h}$, kąt uderzenia $20^{\circ}$ ) dla bariery mostowej z krawężnikiem o wysokości $14 \mathrm{~cm}$,

- TB32 dla połączenia bariery linowej z barierą stalową,

- TB51 dla bariery stalowej i kolumny oświetleniowej umieszczonej w szerokości pracującej bariery,

- TB41 (pojazd o masie $10000 \mathrm{~kg}$, prędkość uderzenia $70 \mathrm{~km} / \mathrm{h}$, kąt uderzenia $8^{\circ}$ ) dla bariery betonowej,

- TB32 dla drogowej bariery linowej (kąt uderzenia $7^{\circ}$ ),

- TB32 dla drogowej bariery stalowej (kąt uderzenia $7^{\circ}$ ).
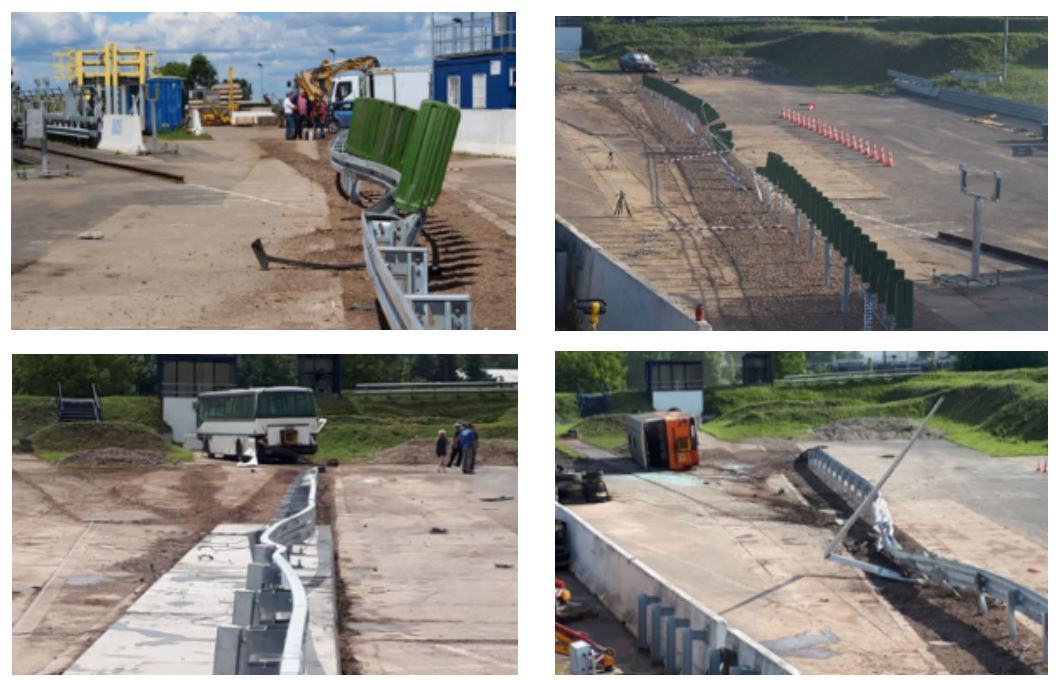

Rys. 1. Dokumentacja fotograficzna $\mathrm{z}$ testów zderzeniowych przeprowadzonych w ramach projektu ROSE 


\subsection{Analiza wyników badań}

Zebrane w wyników testów zderzeniowych dane umożliwiły przeprowadzenie analizy wpływu energii uderzenia pojazdu $\mathrm{w}$ barierę na zmianę parametrów funkcjonalnych bariery. Pojazd uderzający w barierę powoduje jej ugięcie lub zniszczenie. Wielkość ugięcia bariery po uderzeniu w nią pojazdu zależy od energii uderzenia pojazdu w barierę oraz jej cech konstrukcyjnych, wpływających na odporność na odkształcenia. Energia kinetyczna poprzeczna uderzającego w barierę pojazdu EKL zależy od masy uderzającego pojazdu MP, prędkości uderzenia VP i kąta uderzenia pojazdu w barierę drogową KU. Energię kinetyczną poprzeczną EKL pojazdu uderzającego w barierę określono za pomocą wzoru (1):

$\frac{M P \cdot(V P \cdot \sin (K U))^{2}}{2}$

$$
E K L=
$$

Odkształcenia bariery $\mathrm{w}$ wyniku uderzenia $\mathrm{w}$ nią pojazdu normatywnego określa się znormalizowanymi wartościami: ugięcia dynamicznego DM i szerokości pracującej WM. Odporność na odkształcenia barier drogowych spowodowana uderzeniem pojazdu może być mierzona za pomocą miar, takich jak: sztywność K i szerokość pracująca WM.

Sztywność konstrukcji bariery K jest to zdolność bariery do stawiania oporu na uderzenia pojazdu, można zmierzyć jako iloraz siły charakteryzującej uderzający pojazd i odległości na jaką została przesunięta bariera w wyniku uderzenia w nią pojazdu. Sztywność K bariery drogowej można określić za pomocą wzoru (2):

$$
K=\frac{M P \cdot(V P \cdot \sin (K U))^{2}}{D M^{2}}(2)
$$

Poziom ciężkości (intensywności) zderzenia pojazdu z barierą określa poziom ciężkości obrażeń, które mogą być poniesione przez osoby znajdujące się $\mathrm{w}$ pojeździe w chwili uderzenia pojazdu w barierę drogową o określonym poziomie powstrzymywania. Poziom intensywności zderzenia mierzony jest za pomocą wskaźnika ASI, określanego za pomocą wzoru (3), którego parametry ustalane są w trakcie testu zderzeniowego.

$$
A S I=\max \left[\left(\frac{a_{x}}{12 g}\right)^{2}+\left(\frac{a_{y}}{9 g}\right)^{2}+\left(\frac{a_{z}}{10 g}\right)^{2}\right]^{\frac{1}{2}}
$$

Oznaczenia: 
EKL - energia kinetyczna poprzeczna (boczna) pojazdu (kJ),

MP - masa pojazdu (kg),

VP - prędkość uderzenia pojazdu w barierę $(\mathrm{m} / \mathrm{s})$,

KU - kąt uderzenia pojazdu w barierę (stopnie),

DM - ugięcie dynamiczne bariery po uderzeniu pojazdu (m),

$\mathrm{K}$ - sztywność konstrukcji bariery drogowej $\left(\mathrm{kN} / \mathrm{m}, \mathrm{kJ} / \mathrm{m}^{2}\right)$,

$\mathrm{a}_{\mathrm{x}, \mathrm{y}, \mathrm{z}}$ - średnie przyspieszenia pojazdu pomierzone w czasie testu zderzeniowego, odpowiednio w kierunku podłużnym, poprzecznym i pionowym zmierzone w określonym przedziale czasu (50 milisekund).

\section{Wyniki}

Wykorzystując przeprowadzone testy zderzeniowe wykonano badania wpływu energii uderzenia pojazdu $\mathrm{w}$ barierę EKL na zmianę parametrów funkcjonalnych bariery. Badania te obejmowały zbiór analiz, które umożliwiły określenie wpływu uderzeń pojazdu $\mathrm{w}$ barierę drogową na parametry bariery istotne do budowy modeli, służących do szacowania wielkości ugięcia dynamicznego bariery DM, szerokości pracującej WM i wielkość wskaźników ciężkości zdarzeń ASI. Ugięcie dynamiczne bariery DM charakteryzuje dynamiczną pracę bariery $\mathrm{w}$ trakcie uderzenia pojazdu w barierę. Na podstawie zebranych danych z testów zderzeniowych opracowano modele zależności ugięcia dynamicznego bariery DM od sztywności bariery $\mathrm{K}$, energii kinetycznej poprzecznej uderzającego w barierę pojazdu EKL oraz masy pojazdu MP (4).

$$
D M=4,7 \cdot K^{-0,5} \cdot \exp \left(1,1 \cdot \frac{E K L}{100}-0,14 \cdot \frac{M P}{1000}\right)
$$

$\mathrm{Na}$ rys. 2 przedstawiono wykres zależności znormalizowanego ugięcia dynamicznego bariery DM od sztywności bariery $\mathrm{K}$, energii kinetycznej poprzecznej EKL pojazdu uderzającego w barierę oraz masy tego pojazdu MP. Ugięcie dynamiczne bariery DM zwiększa się wraz ze wzrostem energii kinetycznej poprzecznej pojazdu EKL, a zmniejsza się wraz ze wzrostem sztywności bariery K oraz masy pojazdu MP uderzającego w barierę. Szerokość pracująca bariery WM jest parametrem technicznym, charakteryzującym sztywność lub podatność bariery drogowej na uderzenia pojazdów, wykorzystywanym do projektowania bariery w przekroju poprzecznym drogi. $\mathrm{Na}$ podstawie zebranych danych $\mathrm{z}$ testów zderzeniowych opracowano także modele zależności szerokości pracującej bariery WM od ugięcia dynamicznego bariery DM oraz od szerokości bariery WB (5). 


$$
M=0,87 \cdot D M^{1,28}+1,005 \cdot W B
$$

Na rys. 3 przedstawiono wykres zależności znormalizowanej szerokości pracującej WM od ugięcia dynamicznego DM i szerokości bariery WB. Z uzyskanych danych wynika, że szerokość pracująca bariery WM rośnie wraz ze wzrostem ugięcia dynamicznego DM i szerokości bariery WB. Poziom ciężkości (intensywności) zderzenia pojazdu z barierą, mierzony wskaźnikiem ASI określa poziom ciężkości obrażeń osób znajdujących się w pojeździe w momencie uderzenia pojazdu w barierę drogową o określonej sztywności bariery.

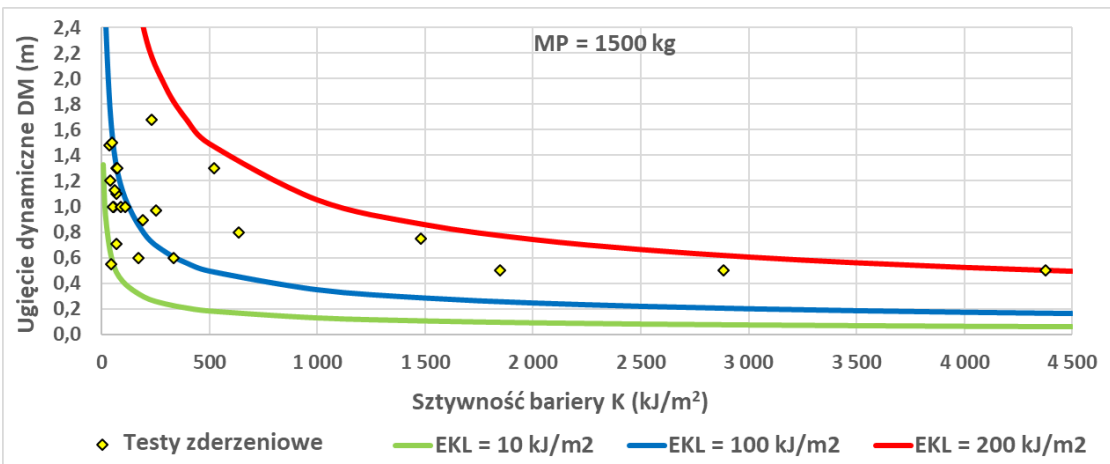

Rys. 2. Wykres zależności znormalizowanego ugięcia dynamicznego bariery DM od sztywności bariery K, energii kinetycznej poprzecznej EKL uderzającego pojazdu w barierę oraz masy pojazdu MP

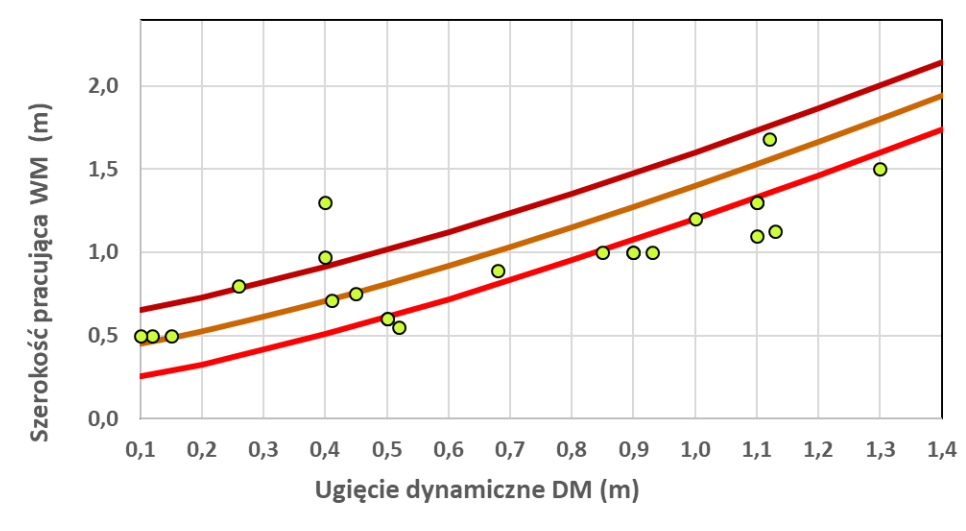

○ Testy zderzeniowe -WB=0,2 $m \quad-W B=0,4 m \quad-W B=0,6 m$

Rys. 3. Wykres zależności pomiędzy ugięciem dynamicznym bariery DM a szerokością pracującą bariery WM 
Na podstawie zebranych danych z testów zderzeniowych opracowano także modele zależności wskaźnika intensywności zderzenia ASI od ugięcia dynamicznego bariery DM, energii kinetycznej poprzecznej EKL i energii kinetycznej podłużnej EKP (6).

$$
A S I=1,64 \cdot \exp \left(7,72 \cdot \frac{E K L}{1000}+1,24 \cdot \frac{E K P}{1000}-0,68 \cdot D M\right)
$$

Na rys. 4 przedstawiono wykres zależności wskaźnika ASI od ugięcia dynamicznego bariery DM i energii kinetycznej poprzecznej pojazdu EKL. Wartość wskaźnika ASI rośnie wraz ze wzrostem sztywności bariery (zmniejszaniem się ugięcia dynamicznego DM) oraz ze wzrostem energii kinetycznej poprzecznej EKL pojazdu uderzającego w barierę drogową.

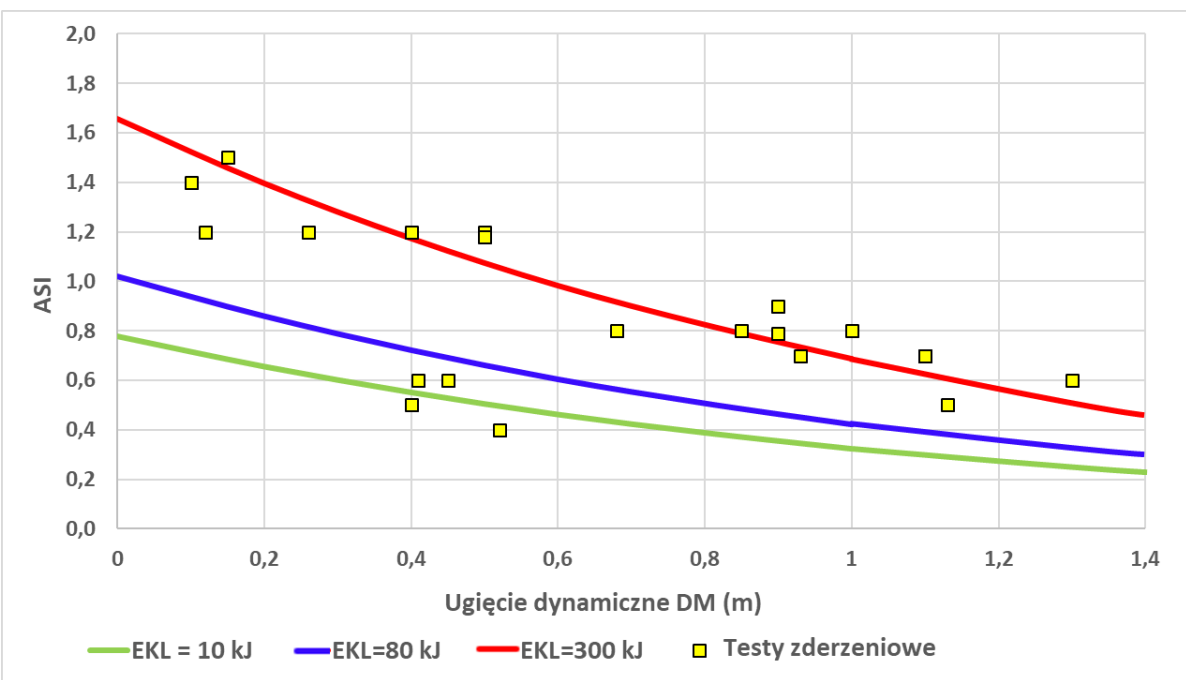

Rys. 4. Wykres modelowych zależności pomiędzy ugięciem dynamicznym bariery DM a wskaźnikiem ASI

\section{Podsumowanie}

Badania wpływu rodzaju urządzeń brd i ich zastosowania w różnych warunkach drogowo - ruchowych na funkcjonalność i bezpieczeństwo urządzeń brd zastosowanych na różnych obiektach drogowych stanowią podstawę do formułowania nowoczesnych metod projektowania, budowy i eksploatacji infrastruktury drogowej 
z uwzględnieniem istotnej roli tych urządzeń w zapewnieniu bezpieczeństwa infrastruktury drogowej. Wyniki przeprowadzonych prac badawczych posłużą także do opracowania zbioru rekomendacji i zaleceń do stanowiących podstawę do sformułowania nowych wytycznych dla projektantów, producentów i wykonawców urządzeń brd oraz instrukcji dla firm utrzymujących te urządzenia. Zastosowanie wytycznych pozwoli na kształtowanie bezpiecznej infrastruktury drogowej i umożliwią wyeliminowanie najczęściej stosowanych dotychczas błędów. Przeprowadzone badania poligonowe pozwoliły na wstępne opisanie czynników wpływających na wielkość uszkodzeń barier w wyniku uderzenia w nie pojazdu oraz na wielkość zagrożeń dla uczestników ruchu w pojazdach. Na podstawie analizy uzyskanych wyników można stwierdzić, że:

- podstawowe parametry charakteryzujące cechy konstrukcyjne drogowej bariery ochronnej, tj. szerokość pracująca WM i ugięcie dynamiczne DM, zależą od sztywności bariery (mierzonej parametrem $\mathrm{K}$ ) oraz energii kinetycznej poprzecznej EKL, z jaką pojazd uderza w barierę,

- wskaźnik ciężkości zdarzeń ASI rośnie wraz ze wzrostem sztywności bariery (mierzonej ugięciem dynamicznym DM) oraz wzrostem wielkości energii kinetycznej poprzecznej EKL pojazdu uderzającego w barierę.

Przeprowadzone analizy wyników badań, które uzyskano ze standardowych testów zderzeniowych pojazdów $\mathrm{z}$ barierą drogową, przeprowadzonych na poligonach badawczych, pozwalają na określenie wpływu, tylko wybranych czynników związanych z uderzeniem pojazdu w barierę, na zmianę parametrów funkcjonalnych i konstrukcyjnych drogowej bariery ochronnej. Natomiast wyniki otrzymanych testów zderzeniowych umożliwią kalibrację modeli numerycznych drogowych barier ochronnych, za pomocą których przeprowadzone będą badania symulacyjne ich funkcjonowania, pozwalające na poszerzenie zakresu badań Wyniki przeprowadzonych badań symulacyjnych będą przedstawione w kolejnych publikacjach.

\section{Literatura}

1. AASHTO. Roadside Design Guide, 2011.

2. Ambros J., Havránek P., Valentová V., Křivánková Z., Striegler R.: Identification of Hazardous Locations in Regional Road Network - Comparison of Reactive and Proactive Approaches. Transp. Res. Procedia, vol. 14, 2016.

3. Barnat W., Bogusz P. Dziewulski P., Gieleta R., Kiczko A., Klasztorny M., Niezgoda T., Ochelski S.: Experimental validation of the numerical model of a car impact on a road barrier, Journal of KONES Powertrain and Transport, Vol. 17, No. 1, 2010. 
4. Borkowski W., Hryciów Z., Rybak P., Wysocki J., Wiśniewski A.: Studies on the effectiveness of the innovative road safety system, Journal of KONES Powertrain and Transport, Vol. 21, No. 2, 2014.

5. Budzyński M., Gobis A., Jamróz K., Jeliński L., Ostrowski K.: Road Restraint Systems as a Basis for Roadside Safety Improvement. WMCAUS 2018, IOP Conference Series: Materials Science and Engineering, 2019.

6. Budzyński M., Jamróz K., Jeliński Ł.: Assessment of Road Restraint Systems in Polish Conditions. Journal of KONBiN, vol. 45, iss. 1, 2018, doi.org/10.2478/jok-2018-0017.

7. Budzyński M., Jamróz K., Marcin A.: Effect of the Road Environment on Road Safety in Poland. WMCAUS 2017: IOP Conference Series: Materials Science and Engineering, vol. 245, 2017.

8. Budzyński M., Jamróz K., Jeliński L., Antoniuk M.: Why are Trees Still Such a Major Hazard to Drivers in Poland?. Transport Research Arena 2016. Transportation Research Procedia, 2016.

9. Burbridge A., Troutbeck R.: Decompartmentalising road safety barrier stiffness in the context of vehicle occupant risk. Proceedings of the 2016 Australasian Road Safety Conference, Australia 2017.

10. De Ridder S., Van der Horst R., Naing C., Thomson R.: Identify envelope of vehicle and driver response prior to collisions. RISER, 2006.

11. EN 1317-2:2010. Road restraint systems - Part 2: Performance classes, impact tests acceptance criteria and test methods for safety barriers including vehicle parapets.

12. Fitzpatrick C. D.: The Effect of Roadside Elements on Driver Behavior and Run-Offthe-Road Crash Severity, 2014.

13. Francesca P., Torre L.: SAVeRS Selection of Appropriate Vehicle Restraint Systems. 2014.

14. Goubel C., Di Pasquale E., Massenzio M., Ronel S.: Comparison of crash tests and simulations for various vehicle restraint systems. 7th European LS-DYNA Conference, Salzburg, Austria 2009.

15. Grzyl B., Kristowski A., Jamróz K., Gobis A.: Methods of estimating the cost of traffic safety equipment's life cycle. MATEC Web Conf., 2017.

16. Hallquist J. O.: LS-DYNA theory manual. Livermore Software Technology Corporation, 2006.

17. Holdridge J. M., Shankar V. N., Ulfarsson G. F.: The crash severity impacts of fixed roadside objects. J. Safety Res., vol. 36, no. 2, 2005.

18. Jamieson N., Waibl G., Davies R.: Use of roadside barriers versus clear zones, 2013.

19. Jamróz K., Burzyński S., Witkowski W., Wilde K.: Numerical methods for the assessment of bridge safety barriers. In M. Kleiber et al., eds. Advances in Mechanics: Theoretical, Computational and Interdisciplinary Issues, Gdańsk 2015.

20. Jurewicz C., Troutbeck R. J., Jurewicz C., Troutbeck R.: A Safe System-based approach to selection of clear zones, safety barriers and other roadside treatments. Australas. Road Saf. Res. Polic. Educ. Conf., 2012. 
21. Karim H., Magnusson R., Natanaelsson K.: Life-Cycle Cost Analyses for Road Barriers. J. Transp. Eng., vol. 138, no. 7, 2012.

22. Klasztorny M., Zielonka K., Nycz D. B., Posuniak P., Romanowski R. K.: Experimental validation of simulated TB32 crash tests for SP-05/2 barrier on horizontal concave arc without and with composite overlay. Arch. Civ. Mech. Eng, vol. 18, 2018, doi:10.1016/j.acme.2017.07.007.

23. La Torre F.: Forgiving Roadsides Design Guide. CEDR, 2012.

24. Niezgoda T., Barnat W., Dziewulski P., Kiczko A.: Numerical modelling and simulation of road crash tests with the use of advanced CAD/CAE systems. Journal of KONBiN, 3 (23), 2012, DOI 10.2478/jok-2013-0041.

25. Norwegian Public Roads Administration, Vehicle Restraint Systems and Roadside Areas. NPRA Directorate of Public Roads, 2014.

26. Nycz D. B.: Comparison of functionality of type a and $b$ guide rails of steel road safety barriers. The Baltic Journal of Road and Bridge Engineering, vol. 13(3), 2018.

27. Ogden K. W.: Safer roads: a guide to road safety engineering. Avebury Technical, 1996.

28. PD CEN/TR 16303:2012 Road restraint systems - Guidelines for computational mechanics of crash testing against vehicle restraint system, 2012.

29. Ray M. H., Asce M., Silvestri C., Conron C. E. Mongiardini M.: Experience with Cable Median Barriers in the United States: Design Standards, Policies, and Performance. Journal of Transportation Engineering, 2009.

30. Ren Z., Vesenjak M.: Computational and experimental crash analysis of the road safety barrier. Engineering Failure Analysis, vol. 12, iss. 6, 2005.

31. Sicking D. L., Ross Jr. H. E.: Benefit-Cost Analysis of Roadside Safety Alternatives. Transportation Research Record, 1986.

32. Vasenjak M., Borovinšek M., Ren Z.: Computational simulations of road safety barriers using LS-DYNA, 6. LS-DYNA Anwenderforum, Frankenthal, DYNAmore $\mathrm{GmbH}, 2007$. 